\title{
Effect of dietary protein levels on growth performance, hematological parameters and digestive enzymes in juveniles of Brycon amazonicus (Spix \& Agassiz, 1829)
}

\author{
Anny Cristina V. Leite ${ }^{1}$, Jackson Pantoja-Lima ${ }^{1,2}$, Renan R. Paulino ${ }^{3}$, Márcia Regina Fragoso M. Bussons ${ }^{4}$, Rodrigo Y. \\ Gimbo $^{5}$, Wallice Luiz P. Duncan ${ }^{6}$, Paulo Henrique R. Aride ${ }^{7}$, Caterina Faggio ${ }^{8}{ }^{*}$, Adriano T. Oliveira ${ }^{7}$ and Bruno O.

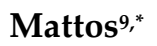

1 Postgraduate Program in Animal Science and Fisheries Resources, Federal University of Amazonas (UFAM), Manaus 69080-900; anny_leite@hotmail.com

2 Aquaculture Laboratory, Federal Institute of Education, Science and Technology of Amazonas (IFAM), Presidente Figueredo 69735-000; jackson.lima@ifam.edu.br

3 Department of Animal Science, Federal University of Lavras (UFLA), Lavras 37200-900; renanrpaulino@hotmail.com

4 Master of Professional Engineering, Galileo institute of Technology and Education of the Amazon (ITEGAM), Manaus 69020-030; mmachadobussons@gmail.com

5 Postgraduate Program in Aquaculture, University Nilton Lins (UNINILTON), Manaus 69058-030; rodrigo.gimbo@uniniltonlins.edu.br

6 Institute of Biological Sciences, Federal University of Amazonas (UFAM), Manaus 69077-000; wduncan@ufam.edu.br

7 Morphophysiology Laboratory, Federal Institute of Education, Science and Technology of Amazonas (IFAM), Manaus 69020-120; aride@ifam.edu.br, adriano.oliveira@ifam.edu.br

8 Department of Chemical, Biological, Pharmaceutical and Environmental, University of Messina, 98122; cfaggio@unime.it

9 Department of Fisheries Engineering, Federal University of Recôncavo da Bahia (UFRB), Cruz das Almas 44380-000; mattos.bo@gmail.com

* Correspondence: Correspondence: cfaggio@unime.it (C.F.); mattos.bo@gmail.com (B.O.M.)

\begin{abstract}
A 52-day experiment was conducted to determine the crude protein $(\mathrm{CP})$ requirements of juvenile matrinxã Brycon amazonicus, and to evaluate their resulting growth performance, hematological parameters and enzymatic activities. Sixty fish $(29.03 \mathrm{~g} \pm 1.16 \mathrm{~g})$ were distributed in 12 tanks $(310 \mathrm{~L})$ with a completely randomized design, and maintained at four dietary crude protein levels $\left(270,320,350,390 \mathrm{~g} . \mathrm{kg}^{-1}\right)$ for 52 days. The results revealed that the fish fed diet $390 \mathrm{~g} \cdot \mathrm{kg}^{-1} \mathrm{CP}$ had the best final weight, weight gain, feed conversion ratio, specific growth rate, protein efficiency ratio and lipid retention rate. The same could be stated for hematocrit, number of circulating erythrocytes, triglycerides and total proteins of the hematological profile $(\mathrm{p}<0.05)$. In the whole body composition, dry matter content was lower in the fish fed 390 g.kg-1 $\mathrm{CP}$, while lipid content was higher in the fish fed $350-390$ g.kg-1 $\mathrm{CP}(\mathrm{p}<0.05)$. No differences were observed in $\mathrm{CP}$ and ash $(p>0.05)$, or in the activities of digestive enzymes ( $p>0.05$ ). In short, our findings suggest benefits of the 390 g.kg-1 CP feed for being the most adequate for this species' juvenile stage.
\end{abstract}

Keywords: feed formulation; protein requirement; nutrition

\section{Introduction}

In animal production segments, aquaculture is the fastest growing activity in the world because the world's population is eating more fish, which is a driver of higher production [1]. During the fish breeding process, supplying diets that meet the nutritional requirements of a given species and breeding stage is one of the determining factors for productive efficiency, and is related to zootechnical performance [2-3]. Understanding how nutrition influences fish metabolism and health allows us to formulate adequate diets that meet species requirements, and are viable from the 
zootechnical and financial points of view [4]. Of all nutrients, protein is the most important because it makes up about $65-75 \%$ of total fish weight (based on dry matter) [5]. Therefore, adequate protein supply is necessary to not only allow proper fish development, but to also preserve water quality in breeding tanks [6]. Of all the nutrients used in diet formulation, protein is one of the main obstacles for fish farming to develop in the Amazon [7].

The activities of digestive enzymes influence how fish use food. Understanding these activities is important because it allows us to optimize fish diet formulation [8]. As blood is one of the most dynamic tissues of the organism, and changes in it occur according to the type of diet consumed, it is possible to evaluate fish nutritional status by analyzing hematological characteristics [9, 10]. Knowledge of the mean values of hematological parameters in the natural fish environment and captivity in the most diverse commercial breeding systems is important for identifying physiological changes due to nutrition and environmental factors, such as homeostasis conditions and stress [11].

Of the native fish species farmed in the State of Amazonas, tambaqui (Colossoma macropomum), matrinxã (Brycon amazonicus), and pirarucu (Arapaima gigas) are the most noteworthy [12]. Matrinxã is the second most cultivated species in the State of Amazonas, and the most cultivated species in the northern and central mesoregions of this state for its superior zootechnical performance, quality and good consumer acceptance [13]. It also adapts easily to the efficient use of protein sources of either animal or vegetable origin [14]. However, information on crude protein (CP) levels in matrinxã diets is still divergent, which evidences the need for research to generate knowledge about the protein needs of this species' juveniles [15].

In this context, the present study evaluated increasing $\mathrm{CP}$ levels in the diet of juvenile matrinxã $\left(270,320,350,390 \mathrm{~g} / \mathrm{kg}^{-1} \mathrm{CP}\right)$, and correlated them with zootechnical performance, hematological parameters and the determination of digestive enzyme activity. This study sought to establish the ideal protein level for this species' juvenile phase to achieve food efficiency and to optimize production.

\section{Materials and Methods}

\subsection{Experimental diets}

Four experimental isoenergetic diets (16.74 MJ crude energy/kg) with increasing protein levels $\left(270,320,350,390 \mathrm{~g} / \mathrm{kg}^{-1} \mathrm{CP}\right)$ were used (Table 1). Diets were formulated based on nutritional recommendations for omnivorous fish species [16]. Formulations were prepared in the Aquatic Organism Nutrition Laboratory at the Nilton Lins University. Ingredients were milled in a $0.5 \mathrm{~mm}$ mesh knife mill (Wiley Mill, TE-650/1), homogenized in a humidified " $Y$ " automatic mixer (20\% water) and processed in a single thread extruder through a $4 \mathrm{~mm}$ dye. Then they were dried in a forced ventilation oven at $55^{\circ} \mathrm{C}$ for $24 \mathrm{~h}$ and kept in a freezer until they were used at $-18^{\circ} \mathrm{C}$.

Table 1. Composition and proximate analyses of experimental diets.

\begin{tabular}{lcccc}
\hline \multirow{2}{*}{ Ingredients (g/Kg of dry weight) } & \multicolumn{3}{c}{ Dietary protein levels $\left(\mathrm{g} . \mathrm{Kg}^{-1}\right)$} \\
\cline { 2 - 5 } & 270 & 320 & 350 & 390 \\
\hline Soybean meal & 165.20 & 240.30 & 315.80 & 390.20 \\
Fish meal & 250.00 & 250.00 & 250.00 & 250.00 \\
Corn Gluten & 0.00 & 18.00 & 36.00 & 54.00 \\
Wheat bran & 150.00 & 150.00 & 150.00 & 150.00 \\
Corn bran & 297.80 & 215.40 & 133.00 & 50.60 \\
Soybean oil & 50.00 & 50.00 & 50.00 & 50.00 \\
Dicalcium phosphate & 15.00 & 15.00 & 15.00 & 15.00
\end{tabular}




\begin{tabular}{|c|c|c|c|c|}
\hline Premix $^{1}$ & 10.00 & 10.00 & 10.00 & 10.00 \\
\hline Sodium chloride & 5.00 & 5.00 & 5.00 & 5.00 \\
\hline $\mathrm{BHT}^{2}$ & 0.20 & 0.20 & 0.20 & 0.20 \\
\hline Benzoic acid & 5.00 & 5.00 & 5.00 & 5.00 \\
\hline Cellulose & 10.00 & 10.00 & 10.00 & 10.00 \\
\hline Inert & 41.70 & 31.10 & 20.00 & 10.00 \\
\hline Total & 1000.00 & 1000.00 & 1000.00 & 1000.00 \\
\hline \multicolumn{5}{|c|}{ Proximate composition (g.Kg-1) } \\
\hline Dry matter ${ }^{3}$ & 961.10 & 962.90 & 960.30 & 955.50 \\
\hline Crude protein ${ }^{3}$ & 270.90 & 320.80 & 356.60 & 397.30 \\
\hline Crude fat $^{3}$ & 141.60 & 130.50 & 130.80 & 128.10 \\
\hline $\mathrm{Ash}^{3}$ & 131.10 & 125.70 & 118.30 & 111.90 \\
\hline Crude fiber ${ }^{3}$ & 43.40 & 61.40 & 50.30 & 43.80 \\
\hline $\mathrm{NFE}^{4}$ & 374.10 & 331.50 & 304.30 & 274.40 \\
\hline
\end{tabular}

${ }^{1}$ Composition of vitamin-mineral premix $(\mathrm{mg} / \mathrm{kg}$ diet $)$ : Vit. A $(\mathrm{min})=1.200 .000$ UI; Vit. D3 $(\mathrm{min})=$ 200.000 UI; Vit. E (min) = $12.000 \mathrm{mg}$; Vit. K3 (min) = $2.400 \mathrm{mg}$; Vit. B1 (min) = $4.800 \mathrm{mg}$; Vit. B2 (min) $=4.800 \mathrm{mg}$; Vit. B6 $(\mathrm{min})=4.000 \mathrm{mg}$; Vit. B12 $(\mathrm{min})=4.800 \mathrm{mg}$; Vitamin C = $48.000 \mathrm{mg}$; Folic acid $(\mathrm{min})=1.200 \mathrm{mg}$; Pantothenic acid $(\mathrm{min})=12.000 \mathrm{mg} ;$ Biotin $(\mathrm{min})=48 \mathrm{mg}$; Choline $(\mathrm{min})=65.000$ $\mathrm{mg}$; Niacin $(\mathrm{min})=24.000 \mathrm{mg}$; Iron $(\mathrm{min})=10.000 \mathrm{mg}$; Copper $(\mathrm{min})=600 \mathrm{mg}$; Manganese $(\min )=$ $4.000 \mathrm{mg} ;$ Zinc $(\mathrm{min})=6.000 \mathrm{mg} ;$ Iodine $(\mathrm{min})=20 \mathrm{mg} ;$ Cobalt $(\mathrm{min})=2 \mathrm{mg} ; \quad$ Selenium $(\mathrm{min})=20$ mg. ${ }^{2}$ Butyl hydroxy toluene. ${ }^{3}$ Analysed values according to AOAC (2012). ${ }^{4}$ NFE: Nitrogen-free extract (NFE).

\subsection{Feeding trial}

This study was carried out following the recommendations on Ethical Principles in Animal Experimentation adopted by the Brazilian National Council for Animal Experimentation Control (CONCEA). It was approved by the Ethical Animal Use Commission (CEUA) at the Nilton Lins University with approval No. 017/2016 and at the Federal University of Amazonas with approval $N^{\circ}$. 001/2017. All the experimental procedures were followed according to local guidelines [17]. The trial was conducted in Manaus, Amazonas (Brazil). The experimental system consisted of 12 tanks (310 L) in a system with partial water renewal and constant artificial aeration. During the trial, fish were fed 3 times ( 8 and 12 am, and 5 pm) a day until apparent satiety. Water parameters, such as temperature, $\mathrm{pH}$, oxygen and ammonia, were measured daily, with respective values of $29 \pm 0.80^{\circ} \mathrm{C}, 6.25 \pm 0.50,7.80 \pm 0.60 \mathrm{mg} / \mathrm{L}$ and $0.25 \pm 0.10 \mathrm{mg} / \mathrm{l}$, following Resolution $N^{\circ} .357$ of 2005, of the National Council of the Environment (CONAMA) for freshwater. The photoperiod was maintained at 12h:12h light: dark.

Juvenile matrinxã Brycon amazonicus $(\mathrm{N}=60)$ were acquired from the Center for Technological Training and Production in Aquaculture (CTTPA) in the municipality of Presidente Figueiredo, State of Amazonas. They were allowed 10 days to adapt to laboratory conditions. Juvenile matrinxã, with a $29.03 \mathrm{~g} \pm 1.1$ mean initial weight, were randomly distributed to tanks at a density of five fish per tank, and each experimental diet was randomly assigned to three replications.

At the end of the 52-day feeding trial, fish were counted and weighed after not being fed for $24 \mathrm{~h}$ and four fish per tank were randomly sampled. Two of these fish were immediately euthanized by a $50 \mathrm{mg} / \mathrm{L}$ clove oil overdose [18] and frozen for the body composition analysis. Two other sampled fish were used for blood and tissue collections. Blood was obtained from the caudal vein and stored separately in tubes with or without $10 \%$ EDTA. Blood samples without anticoagulants were centrifuged at $3000 \mathrm{rpm}$ for 15 minutes $3 \mathrm{~h}$ after blood clotting to obtain plasma [19]. Plasma was recovered after centrifugation at $3000 \mathrm{rpm}$ for 15 minutes and stored at $-80^{\circ} \mathrm{C}$ until the analyses. 
Therefore, fish were killed by clove oil overdose (50 mg/L) [18]. Fish length and weight, and viscera and liver weights, were recorded to determine the body index. The stomachs, intestines and livers of these fish were collected and stored at $-80^{\circ} \mathrm{C}$ until the analyses.

\subsection{Growth parameters}

The effects of the experimental diets on zootechnical performance, feed utilization and the hepato-somatic index were determined by calculating the parameters set out below.

- Weight gain (WG; g): final weight (g) - initial weight (g);

- $\quad$ Feed conversion ratio (FCR): individual feed intake (g)/individual weight gain (g);

- $\quad$ Specific growth rate (SGR; \%/day): [(Ln final weight - Ln initial weight)/Time] $x$ 100;

- Protein efficiency ratio (PER; \%): weight gain (g)/crude protein intake (g);

- Protein retention rate (PRR; \%): \{[(CP final carcass $x$ final weight) - (CP initial carcass $x$ initial weight)] / crude protein intake $\} \times 100$

- $\quad$ Lipid retention rate (LRR; \%): \{[(lipid final carcass $x$ final weight) - (lipid initial carcass $x$ initial weight)] / lipid intake $\}$ x 100

- Hepato-somatic index (HSI; \%): (liver weight/final weight) $\times 100$

- $\quad$ Survival $(\mathrm{S}, \%)=($ number of final animals $\times 100) /$ number of initial animals.

\subsection{Body composition}

Proximate fish compositions were collected from two fish in each experimental unit (6 fish per treatment). Body composition was determined by the standard methods of the Association of Official Analytical Chemists [20]. The following were determined: content moisture by drying for $24 \mathrm{~h}$ at $110^{\circ} \mathrm{C}$ to constant weight; protein by the Kjeldahl method $(\mathrm{N} \times 6.25)$; crude fat by diethyl ether extraction; ash by heating at $450^{\circ} \mathrm{C}$ for $24 \mathrm{~h}$; crude fiber by the Weende method [21]. The nitrogen-free extract (NFE) for diets was determined as the remainder of $\mathrm{CP}$, crude fat, ash and crude fiber.

\subsection{Hematological parameters}

Whole blood was used to evaluate the hematological variables. The determination of the number of circulating erythrocytes $\left(\mathrm{RBC}, \mathrm{x} 10^{6} / \mu \mathrm{L}\right)$ was made in a Neubauer chamber according to the method of Collier [22]; Hematocrit (Htc, \%) was determined by the microhematocrit method, following the methodology of Goldenfarb et al. [23]; hemoglobin concentration $(\mathrm{Hb}, \mathrm{g} / \mathrm{dL})$ was assayed by the cyanometahemoglobin method and spectrophotometer readings [24]. The hematimetric indices were also calculated as established by Wintrobe [25]: mean corpuscular volume (MCV, fL), mean corpuscular hemoglobin $(\mathrm{MCH}, \mathrm{pg})$, and mean corpuscular hemoglobin concentration (MCHC, $\mathrm{g} / \mathrm{dL})$.

The analyses of glucose (enzyme glucose GOD-PAP) and triglycerides (Triglycerides Liquicolor GPO-PAP) were performed from plasma. The analyses of total protein (Total Protein) and cholesterol (Cholesterol Liquicolor) were varied out from serum. All the analyses were run using specific commercial kits (In Vitro Diagnostica Ltda, Itabira/MG) for each parameter, with subsequent readings by a spectrophotometer (Multiskan TM, Thermo Fisher Scientific, Brazil).

\subsection{Enzyme activities}

Stomach and intestines were homogenized in TRIS HCL buffer $50 \mathrm{mM}$ with $\mathrm{CaCl} 2$ at $\mathrm{pH} 8.0$, and the stomach extract in saline containing $\mathrm{CaCl}$. After homogenization, an aliquot of $2.0 \mathrm{~mL}$ of each sample was centrifuged and cooled to $4^{\circ} \mathrm{C}$ for 4 minutes at 10 $\mathrm{rpm}$. The supernatant was stored in tubes and kept frozen at $-80^{\circ} \mathrm{C}$, until the analysis to determine enzyme activity. All enzyme activities were measured at $37^{\circ} \mathrm{C}$ in a microplate reader (Multiskan GO, ThermoScientific, USA), by monitoring changes in absorbance. 
Protein concentration was determined according to Bradford [26] using bovine serum albumin as standard.

To establish acid protease activity, a version of the hemoglobin method adapted by Khaled et al. [27] was followed. A buffer of $100 \mathrm{mM}$ of sodium citrate with $20 \mathrm{mM}$ of $\mathrm{CaCl} 2$ was used and as substrate hemoglobin with $\mathrm{pH}$ 2.0. The reaction was incubated for 60 minutes at $25^{\circ} \mathrm{C}$ and was interrupted by the addition of $50 \mu \mathrm{L}$ of $10 \%$ trichloroacetic acid. The precipitate was removed by centrifugation at $10000 \mathrm{rpm} / 5 \mathrm{~min}$ for the supernatant reading at $275 \mathrm{~nm}$, expressed as $1 \mu \mathrm{mol}$ tyrosine/minute/mg protein. Tyrosine was used as a standard.

To determine alkaline protease activity, a version of the azocasein method adapted by Sarath et al. [28] was employed. As a buffer, $100 \mathrm{mM}$ Tris-HCl, pH 7.6, $20 \mathrm{mM} \mathrm{CaCL2,}$ and $20 \mathrm{mM} \mathrm{NaCl}$ with $0.25 \%$ azocasein were used as a substrate. The reaction was incubated for 60 minutes at $25{ }^{\circ} \mathrm{C}$ and was interrupted by adding $50 \mu \mathrm{L}$ of TCA (10\%). The precipitate was removed by centrifugation at $10000 \mathrm{rpm} / 5 \mathrm{~min}$. for the supernatant reading at $440 \mathrm{~nm}$, expressed as $1 \mu \mathrm{mol}$ of hydrolyzed substrate/mg protein/min.

The non-specific lipase activity in the homogenized stomach and intestine was determined by the methodology adapted from Albro et al. [29] using a mixture of 200 $\mathrm{mM}$ Tris- $\mathrm{HCl}, 10 \mathrm{mM} \mathrm{CaCl} 2,10 \mathrm{~mm} \mathrm{NaCl}, 1 \mathrm{mM}$ Tamodeoxycholate, $0.05 \%$ Triton X-100 and $0.05 \%$ gum Arabic as a buffer at $\mathrm{pH}$ 8.0, and $2 \mathrm{mM}$ P-nitrophenyl-myristate as a substrate. The microplate reading was taken at $405 \mathrm{~nm}$ after hydrolysis and expressed as $1 \mu \mathrm{mol}$ of hydrolyzed substrate/mg of protein/minute.

Amylase was determined by the adapted method Bernfeld [30], by which the reaction was performed using a $100 \mathrm{mM}$ nat acetate buffer at $\mathrm{pH}$ 7.6, with $20 \mathrm{mM} \mathrm{CaCl} 2$ and $10 \mathrm{mM} \mathrm{NaCl}$ and the homogenized product was added and then incubated for 60 minutes at room temperature. The reaction was interrupted by adding $50 \mu \mathrm{L}$ of $1 \%$ starch. The reading was taken at $554 \mathrm{~nm}$ and expressed as $1 \mu \mathrm{mol}$ of glucose/mg of protein/minute. To establish the maltose calibration curve, $50 \mu \mathrm{L}$ lugol diluted to $0.1 \% \mathrm{I} 2$ and $0.3 \%$ I was used.

\subsection{Data analysis}

The results were expressed as mean \pm SEM. Data normality was previously evaluated by the Shapiro-Wilk test and homogeneity of variance was verified by the Levene test. Data were analyzed by a one-way analysis of variance (ANOVA), followed by Tukey's post hoc test, to check for significant differences between treatments. Statistical analyses were conducted using the SPSS software (version 20.0, IBM, Armonk, NY, USA). Differences were considered statistically significant when $\mathrm{p}<0.05$.

\section{Results}

The growth performance and feed efficiency data are presented in Table 2. Fish well accepted the experimental diets and no mortality was recorded. FW, WG, the SGR and the LRR were higher in the fish fed the diet with $390 \mathrm{~g} / \mathrm{kg}^{-1} \mathrm{CP}$, while lower FCR and PER were also observed in this diet. The parameters FW, WG and the SGR showed a positive linear effect with increasing protein inclusion levels. In the whole body composition (Table 3), dry matter content was lower in the fish fed $390 \mathrm{~g} / \mathrm{kg}^{-1} \mathrm{CP}$. Lipid content was higher in the fish fed $350 \mathrm{~g} / \mathrm{kg}^{-1} \mathrm{CP}$. No differences were observed in the $\mathrm{CP}$ and ash of the whole body composition.

No effects by dietary protein were seen for $\mathrm{MCH}, \mathrm{MCV}$ and $\mathrm{MCHC}$ (Table 4). However, hematocrit (Htc) and the number of erythrocytes (RBC) were higher in the fish fed $390 \mathrm{~g} / \mathrm{kg}^{-1} \mathrm{CP}$, while the triglyceride and total plasma protein levels were higher in the fish fed 350 and $390 \mathrm{~g} / \mathrm{kg}^{-1} \mathrm{CP}$. Regarding digestive enzymes, acid protease, alkaline protease, lipase and amylase enzyme activity were evaluated in stomachs, anterior intestines and posterior intestines, and were not affected by dietary treatments (Table 5).

Table 2. Effect of dietary protein levels on growth performance, feed utilization and hepatosomatic index of juvenile matrinxã (Brycon amazonicus) fed experimental diets for 54 days. 


\begin{tabular}{|c|c|c|c|c|c|}
\hline \multirow{2}{*}{ Parameter } & \multicolumn{4}{|c|}{ Dietary protein levels $(\mathrm{g} / \mathrm{Kg})$} & \multirow{2}{*}{$\begin{array}{c}\mathrm{P} \\
\text { Value }\end{array}$} \\
\hline & 270 & 320 & 350 & 390 & \\
\hline $\begin{array}{l}\text { Initial Weight } \\
(\mathrm{g})\end{array}$ & $27.73 \pm 0.87$ & $33.13 \pm 2.29$ & $25.38 \pm 2.09$ & $29.85 \pm 1.69$ & 0.080 \\
\hline $\begin{array}{l}\text { Final Weight } \\
(\mathrm{g})\end{array}$ & $89.20 \pm 3.54^{\mathrm{a}}$ & $100.80 \pm 4.54^{\mathrm{ab}}$ & $90.92 \pm 3.35^{\mathrm{a}}$ & $121.22 \pm 10.59^{b}$ & 0.023 \\
\hline Weight gain (g) & $61.47 \pm 2.97^{a}$ & $67.67 \pm 3.73^{\mathrm{ab}}$ & $65.53 \pm 2.89^{a}$ & $91.37 \pm 8.98^{b}$ & 0.015 \\
\hline Feed intake (g) & $507.62 \pm 18.07$ & $507.95 \pm 13.50$ & $528.62 \pm 16.41$ & $579.05 \pm 73.04$ & 0.557 \\
\hline $\begin{array}{l}\text { Feed } \\
\text { conversion } \\
\text { ratio }\end{array}$ & $1.66 \pm 0.06^{b}$ & $1.51 \pm 0.05^{\mathrm{ab}}$ & $1.74 \pm 0.09 b$ & $1.36 \pm 0.02^{\mathrm{a}}$ & 0.008 \\
\hline $\begin{array}{l}\text { Specific growth } \\
\text { rate }(\%)\end{array}$ & $2.25 \pm 0.05^{\mathrm{ab}}$ & $2.14 \pm 0.10^{\mathrm{a}}$ & $2.46 \pm 0.14^{\mathrm{ab}}$ & $2.69 \pm 0.07^{b}$ & 0.018 \\
\hline $\begin{array}{l}\text { Protein } \\
\text { eficiency ratio } \\
(\%)\end{array}$ & $2.24 \pm 0.07 \mathrm{~b}$ & $2.07 \pm 0.07 \mathrm{ab}$ & $1.81 \pm 0.12^{\mathrm{ab}}$ & $1.68 \pm 0.19 \mathrm{a}$ & 0.044 \\
\hline $\begin{array}{l}\text { Protein } \\
\text { retention rate } \\
(\%)\end{array}$ & $21.33 \pm 0.53$ & $20.08 \pm 0.78$ & $17.22 \pm 0.75$ & $18.97 \pm 1.51$ & 0.081 \\
\hline $\begin{array}{l}\text { Lipid retention } \\
\text { rate }(\%)\end{array}$ & $50.75 \pm 1.21^{\mathrm{a}}$ & $62.76 \pm 1.00^{\mathrm{ab}}$ & $57.07 \pm 4.32^{\mathrm{a}}$ & $73.18 \pm 4.30^{b}$ & 0.010 \\
\hline $\begin{array}{l}\text { Hepato-somatic } \\
\text { index }(\%)\end{array}$ & $1.30 \pm 0.07$ & $1.33 \pm 0.08$ & $1.33 \pm 0.13$ & $1.16 \pm 0.12$ & 0.704 \\
\hline
\end{tabular}

All values represents mean \pm S.E.M., $n=3$ tanks per treatment. Mean in the same row with different superscript letters are significantly different (ANOVA analysis; $\mathrm{P}<.05$ ). The experimental period was 52 day.

Table 3 Effect of dietary protein levels on whole-body composition (g.kg-1 of dry weight) of juvenile matrinxã (Brycon amazonicus) fed experimental diets for 54 days.

\begin{tabular}{lccccc}
\hline \multirow{2}{*}{ Parameter } & \multicolumn{5}{c}{ Dietary protein levels $\left(\mathrm{g} \cdot \mathrm{Kg}^{-1}\right)$} \\
\cline { 2 - 5 } & 270 & 320 & 350 & 390 & P value \\
\hline Dry matter & $344.60 \pm 0.03^{\mathrm{c}}$ & $333.50 \pm 0.05^{\mathrm{b}}$ & $332.10 \pm 0.05^{\mathrm{b}}$ & $320.40 \pm 0.04^{\mathrm{a}}$ & 0.001 \\
Protein & $493.20 \pm 0.57$ & $498.50 \pm 0.47$ & $493.40 \pm 0.78$ & $498.80 \pm 0.76$ & 0.883 \\
Lipid & $409.30 \pm 0.20^{\mathrm{a}}$ & $413.90 \pm 0.12^{\mathrm{a}}$ & $430.00 \pm 0.48^{\mathrm{b}}$ & $422.40 \pm 0.60^{\mathrm{ab}}$ & 0.012 \\
Ash & $74.10 \pm 0.26$ & $83.90 \pm 0.22$ & $79.80 \pm 0.27$ & $82.40 \pm 0.33$ & 0.104 \\
\hline
\end{tabular}

Note: Values in the same line with different letters are significantly different (one-way ANOVA), when submitted to a Tukey test $(\mathrm{p}<0.05)$.

Table 4 Effect of dietary protein levels on hemato-biochemical parameters in juvenile matrinxã (Brycon amazonicus) fed experimental diets for 54 days.

\begin{tabular}{lccccc}
\hline \multirow{2}{*}{ Parameter } & \multicolumn{3}{c}{ Dietary protein levels $\left(\mathrm{g} \cdot \mathrm{Kg}^{-1}\right)$} & \multirow{2}{*}{ P value } \\
\cline { 2 - 5 } & 270 & 320 & 350 & 390 \\
\hline Hematocrit (\%) & $30.69 \pm 0.84^{\mathrm{ab}}$ & $30.14 \pm 0.62^{\mathrm{a}}$ & $32.00 \pm 0.69^{\mathrm{ab}}$ & $33.23 \pm 0.72^{\mathrm{b}}$ & 0.019 \\
\hline
\end{tabular}




\begin{tabular}{lccccc}
\hline Hemoglobin & $1.32 \pm 0.06$ & $1.39 \pm 0.10$ & $1.37 \pm 0.06$ & $1.25 \pm 0.04$ & 0.529 \\
(g/dL) & & & & & \\
RBC $\left(x 10^{6} / \mu L\right)$ & $2.71 \pm 0.11^{\mathrm{a}}$ & $2.68 \pm 0.09 \mathrm{a}$ & $2.80 \pm 0.12^{\mathrm{ab}}$ & $3.34 \pm 0.17 \mathrm{~b}$ & 0.002 \\
$\mathrm{MCH}(\mathrm{pg})$ & $5.05 \pm 0.39$ & $5.35 \pm 0.53$ & $4.87 \pm 0.28$ & $4.13 \pm 0.28$ & 0.168 \\
MCV (fL) & $116.74 \pm 7.26$ & $115.23 \pm 4.02$ & $114.85 \pm 7.73$ & $110.16 \pm 7.07$ & 0.916 \\
MCHC (g/dL) & $4.23 \pm 0.19$ & $4.70 \pm 0.37$ & $4.37 \pm 0.26$ & $3.78 \pm 0.14$ & 0.122 \\
Glucose & $5.06 \pm 0.12$ & $4.82 \pm 0.11$ & $4.76 \pm 0.09$ & $4.95 \pm 0.12$ & 0.256 \\
(mmol/L) & & & & & \\
Triglycerides & $181.87 \pm 8.43^{\mathrm{a}}$ & $177.50 \pm 8.18$ & $118.46 \pm 7.20$ & $138.59 \pm 10.38$ & 0.001 \\
(mg/dL) & & $\mathrm{a}$ & $\mathrm{b}$ & $\mathrm{b}$ & \\
Total proteins & $8.71 \pm 0.22^{\mathrm{a}}$ & $8.25 \pm 0.24^{\mathrm{a}}$ & $6.43 \pm 0.24^{\mathrm{b}}$ & $6.90 \pm 0.33^{\mathrm{b}}$ & 0.001 \\
(g/dL) & & & & & \\
Cholesterol & $89.05 \pm 7.22$ & $93.43 \pm 6.78$ & $69.07 \pm 8.45$ & $100.88 \pm 16.83$ & 0.181 \\
(mg/dL) & & & & & \\
\hline
\end{tabular}

Note: Values in the same line with different letters are significantly different (one-way ANOVA), when submitted to a Tukey test $(\mathrm{p}<0.05)$.

Table 5 Effect of dietary protein levels on digestive enzyme activity in juvenile matrinxã (Brycon amazonicus) fed experimental diets for 54 days.

\begin{tabular}{|c|c|c|c|c|c|}
\hline \multirow{2}{*}{ Enzymes } & \multicolumn{4}{|c|}{ Dietary protein levels (g.Kg-1) } & \multirow{2}{*}{$P$ value } \\
\hline & 270 & 320 & 350 & 390 & \\
\hline \multicolumn{6}{|c|}{ Stomach } \\
\hline Acid Protease (\%) & $185.81 \pm 18.76$ & $171.54 \pm 24.72$ & $132.47 \pm 13.94$ & $130.76 \pm 29.73$ & 0.258 \\
\hline $\begin{array}{l}\text { Alkaline Protease } \\
(\%)\end{array}$ & $0.11 \pm 0.01$ & $0.09 \pm 0.01$ & $0.08 \pm 0.02$ & $0.07 \pm 0.02$ & 0.652 \\
\hline
\end{tabular}

\begin{tabular}{lccccc}
\hline \multicolumn{5}{c}{ Previous intestine } \\
\hline Acid Protease (\%) & $164.96 \pm 16.42$ & $166.73 \pm 10.18$ & $206.22 \pm 11.08$ & $183.97 \pm 27.57$ & 0.244 \\
Alkaline Protease & $0.18 \pm 0.020$ & $0.17 \pm 0.01$ & $0.18 \pm 0.01$ & $0.19 \pm 0.02$ & 0.777 \\
$(\%)$ & & & & \\
Lipase (\%) & $0.24 \pm 0.08$ & $0.16 \pm 0.04$ & $0.17 \pm 0.13$ & $0.06 \pm 0.05$ & 0.509 \\
Amylase (\%) & $1.22 \pm 0.13$ & $0.82 \pm 0.12$ & $0.90 \pm 0.09$ & $0.93 \pm 0.10$ & 0.084 \\
\hline \multicolumn{5}{c}{ Posterior intestine } \\
\hline Acid Protease (\%) & $137.52 \pm 17.32$ & $213.30 \pm 31.09$ & $181.09 \pm 20.23$ & $183.25 \pm 23.67$ & 0.165 \\
Alkaline Protease & $0.19 \pm 0.03$ & $0.21 \pm 0.04$ & $0.17 \pm 0.02$ & $0.20 \pm 0.02$ & 0.729 \\
$(\%)$ & & & & \\
Lipase (\%) & $0.02 \pm 0.003$ & $0.02 \pm 0.004$ & $0.03 \pm 0.01$ & $0.01 \pm 0.002$ & 0.319 \\
Amylase (\%) & $1.37 \pm 0.09$ & $1.76 \pm 0.19$ & $1.69 \pm 0.22$ & $1.45 \pm 0.16$ & 0.362 \\
\hline Note: Values in the same line with different letters are significantly different (one-way ANOVA), \\
when submitted to a Tukey test (p < 0.05).
\end{tabular}

\section{Discussion}

Matrinxã is a carnivorous freshwater fish (trophic level 3.0) with a high cannibalism index in its initial growth phase [31]. In our study, the fish fed the highest CP level in diet 
showed higher growth rates than those that received the lowest CP levels in diet. Similar results have been reported for other carnivorous freshwater fish [32].

The growth performance of the juvenile matrinxã in this study fell within the growth performance range observed in other studies for this species. Our fish with the most WG were those fed $390 \mathrm{~g} / \mathrm{kg}^{-1} \mathrm{CP}$, while the lowest WG value went to the fish fed $270 \mathrm{~g} / \mathrm{kg}^{-1} \mathrm{CP}$. In a study by Izel et al. [15], conducted with juvenile matrinxã submitted to diets with $160,190,220,250$, and $280 \mathrm{~g} / \mathrm{kg}^{-1} \mathrm{CP}$, the highest WG value was obtained in the fish fed $280 \mathrm{~g} / \mathrm{kg}^{-1} \mathrm{CP}$, with FCR values of 2.04 for the $250 \mathrm{~g} / \mathrm{kg}^{-1}$ and $280 \mathrm{~g} / \mathrm{kg}^{-1} \mathrm{CP}$ levels. In the present study, the FCR values for the fish that received $270 \mathrm{~g} / \mathrm{kg}-1$ and $390 \mathrm{~g} / \mathrm{kg}-1$ $\mathrm{CP}$ were 1.66 and 1.36, respectively. This difference could be related to the increase in protein level, which resulted in a better use of diets, and was observed in the FCR. Yang et al. [33] noted this same behavior when evaluating increasing protein levels for Lepomis macrochirus, as did Ullah et al. [34] when they assessed rising protein levels for Tor putitora and observed the same behavior.

The PER had a negative linear effect on the tested diets, which suggests that the highest-level protein diet should not be used for protein deposition and may have been used as an energy source. This statement can be supported by the results found for the PER, the LRR and ether extracts in carcasses because fish retained more body fat when the protein level in diet increased. These results corroborate the findings reported in similar studies $[33 ; 35,36]$.

The highest ether extract content in carcasses was observed in the animals fed the diet with $350 \mathrm{~g} / \mathrm{kg}^{-1}$ of CP. Deposition of lipids in carcasses due to increased dietary protein is not economically desirable $[37,38]$ because the amino acids that derive from protein have to be oxidized to be stored as energy reserves instead of being used for growth.

Blood parameters can be used as biological indicators to monitor fish well-being, particularly as a tool to diagnose animal stress [7;39-41]. The biochemical composition of blood plasma reflects the metabolic situation of tissues in animals. It is also possible to evaluate changes in animal's organ function and adaptation as regards not only nutritional and physiological challenges, but also specific metabolic imbalances or imbalances of a nutritional origin [42,43]. The present study revealed that protein levels do not interfere with the results of hemoglobin and hematimetric indices. The highest hematocrit value was observed in the animals fed a diet containing $390 \mathrm{~g} / \mathrm{kg}^{-1} \mathrm{CP}$. However, this value is considered normal because it falls within the reference values (23-35\%) for the species without causing any health problems [44]. Higuchi et al. [45] fed Rhandia quelen with increasing dietary protein levels and did not observe any differences in the evaluated biochemical and hematological parameters.

Ferreira et al. [46] tested the effects of 360 and $450 \mathrm{~g} / \mathrm{kg}^{-1} \mathrm{CP}$ on diets associated with physical training in physiological parameters of juvenile matrinxã. They concluded that there was no protein level-erythropoietic variation interaction. Puppo et al. [47] evaluated hematological responses of Nile tilapia in relation to increasing CP levels (270, $300,330,360 \mathrm{~g} / \mathrm{kg}^{-1} \mathrm{CP}$ ) in diets. They found no changes in erythropoiesis, which indicates that erythrogram changes are not related to dietary $\mathrm{CP}$ levels.

According to Tavares-Dias et al. [44], the RBC reference values for Brycon amazonicus varied between 1.13-1.56 $\times 106 . \mu \mathrm{L}^{-1}$ ), but the present study obtained higher RBC values (between 2.68-3.34 x106. $\mu \mathrm{L}^{-1}$ ). In studies with Cyprinus carpio, Ahmed and Maqbool [48] observed a linear increase in RBC with varying levels from 250 to $500 \mathrm{~g} / \mathrm{kg}^{-1} \mathrm{CP}$. They attributed this increase to the early release of the storage pool in the spleen. Abdel-Tawwab [49] believed that splenic activity was influenced by protein levels after verifying a linear increase in RBC levels under the influence of protein levels ranging from 250 to $450 \mathrm{~g} / \mathrm{kg}^{-1} \mathrm{CP}$ in Oreochromis niloticus. Different stress factors ranging from handling or forced physical exercise at the time of capturing these animals to performing final biometrics can also influence RBC levels.

The reduction in plasma triglycerides due to the increased protein in experimental diets may be related to greater lipid retention and a higher ether extract concentration in 
carcasses, which might indicate lower circulating triglyceride levels. Glencross et al. [50] observed how lipid retention increased at higher protein levels in the diet of Lates calcarifer. Ahmed and Maqbool [48] reported how incremented protein in diet increased the body lipid concentration in Cyprinus Carpio.

A drop in the total plasma protein levels with increasing protein content in diet may indicate higher protein consumption, as evidenced by the lowering protein efficiency rate. These results agree with Ahmed and Ahmad [51] and Ahmed and Maqbool [48], who demonstrated worse protein efficiency and greater body protein retention in diets with high CP levels for Oncorhynchus mykiss and Cyprinus Carpio, respectively, which may represent lower plasma protein levels, as herein observed.

Regarding digestive enzymes, no differences in activity were observed in the fish fed the experimental diets. Lazzari et al. [8] observed variations in trypsin, chymotrypsin and amylase activity in the digestive tract segments of Rhamdia quelen, and were linked with the protein source composition, which varied between meat and bone meal with sugar cane yeast, soybean meal and fish meal. Non specific acid and alkaline proteases were detected in all the digestive tract segments, but displayed more marked activity in the anterior and posterior intestine segments due to their characteristic alkaline $\mathrm{pH}$. Several studies have correlated proteolytic activity, which varies depending on whether different protein levels for fish are included [52-54]. However, this relation was not observed in the present study, but was ratified by Almeida et al. [55]. Lundsedt et al. [56] conducted a study with juvenile pintado (Pseudoplatystoma corruscans), which were fed 200, 300, 400, and $500 \mathrm{~g} / \mathrm{kg}^{-1} \mathrm{CP}$. These authors observed that the pintado stomach showed marked proteolytic activity but, as this did not respond to diet protein content, they were unable to assume that both enzymes responded to diet.

Lipase activity was not detected in stomachs, and its greatest activity took place in anterior intestines. This result may be correlated with the presence of pyloric caeca, which were homogenized with the anterior intestine portion. Gisbert et al. [57] stated that lipase action was more effective in the proximal portion of intestines and pyloric caeca, whose action extends at a lower activity rate to other digestive tract portions. In the stomach, lipase is responsible for hydrolyzing emulsified and low-melting-point lipids, which demonstrates lower lipolytic performance in this segment. Tok et al. [58] conducted a study on Pangasianodon hypophthalmus and observed only a minor variation in the intestinal lipase enzyme in different protein diets as the same level of lipids was included in all the experimental diets. This finding corroborates the data found in this study. Amylase activity showed no significant differences between treatments and can be localized throughout the fish digestive tract.

\section{Conclusions}

It can be concluded that $390 \mathrm{~g} / \mathrm{kg}^{-1} \mathrm{CP}$ in diet increases zootechnical performance indices in juvenile matrinxã. The inclusion of different protein levels neither leads to hematological alterations nor interferes with the activities of the evaluated digestive enzymes. Future studies should be carried out to determine the ideal digestible protein and amino acid profile and, thus, optimal nutritional requirements.

Author Contributions: Conceptualization, B.O.M., J.L.P., M.R.F.M.B. and A.C.V.L.; methodology, B.O.M., A.C.V.L., R.Y.G., W.L.P.D. and R.R.P.; validation, B.O.M., AC.V.L., A.T.O., C.F. and W.L.P.D.; formal analysis, B.O.M., R.R.P.; A.C.V.L.; A.T.O. and C.F.; investigation, B.O.M., A.C.V.L., R.R.P., R.Y.G., W.L.P.D., J.L.P. and A.T.O.; resources, B.O.M.; W.L.P.D., J.L.P. and M.R.F.M.B.; data curation, B.O.M., R.R.P., A.C.V.L., A.T.O. and C.F.X.X.; writing-original draft preparation, B.OM., A.C.V.L., J.L.P., and M.R.F.M.B.; writing-review and editing, B.O.M., A.C.V.L., R.R.P., A.T.O., C.F., J.L.P., supervision, B.O.M., J.LP. and M.R.F.M.B.; project administration, B.O.M., J.L.P., A.T.O., M.R.F.M.B. and A.C.V.L. All authors have read and agreed to the published version of the manuscript.

Funding: This research received no external funding. 
Institutional Review Board Statement: The study was carried out in accordance with the guidelines of the Declaration of Helsinki, and approved by the Ethics Committee of the Nilton Lins University (017/2016) on July 23, 2018 and the Federal University of Amazonas (001/2017) on July 23, 2018.

Informed Consent Statement: Not applicable.

Data Availability Statement: Available upon request from the corresponding author of this article.

Acknowledgments: The authors wish to thank Marcelo dos Santos Nascimento, Elcimar Sousa, Ariany Rabelo, and Rosemery Menezes Frisso for their technical support. A. T. O. (process 315713/2020-8) is CNPq research fellows.

Conflicts of Interest: The authors declare no conflict of interest.

\section{References}

1. FAO. World Review - Aquaculture production. In The State of World Fisheries and Aquaculture, 1nd ed.; CC BY-NC-SA 3.0 IGO; FAO: Rome, Italy, 2020; Volume 1, pp. 21-35.

2. Aride, P.H.R.; Oliveira, A.M.; Ferreira, M.S.; Liebl, A.R.S.; Comassetto, L.E.; Ladislau, D.S.; Bassul, L.A.; Silva, B.R.; Mattos, D.C.; Lavander, H.D.; Souza, A.B.; Polese, M.F.; Ribeiro, M.W.S.; Castro, P.D.S.; Oliveira, A.T. Growth and hematological responses of tambaqui, Colossoma macropomum fed different levels of rice, Oryza spp.. Braz J Biol 2020, 81, 1-7.

3. Polese, M.F.; Polese, M.F.; Radael, M.C.; Mendonca, P.P.; Motta, J.H.S.; Azevedo, R.V.; Souza, A.B.; Shimoda, E.; Lavander, H.D.; Aride, P.H.R.; Oliveira, A.T.; Vidal Junior, M.V. Zootechnical parameters of Corn feed particle size in performance, digestibility and rate of passage in juvenile tambaqui Colossoma macropomum. Braz J Biol 2022, 82, 1-13.

4. Bicudo, A.J.A.; Abimorad, E.G. Nutrição adequada a cada espécie é desafio para a pesquisa e produção. Visão Agríc 2012, 11, 77-79.

5. Lima, C.A.S.; Bussons, M.R.F.M.; Oliveira, A.T.; Aride, P.H.R.; O'Sullivan, F.L.A.; Pantoja-Lima, J. Socioeconomic and Profitability Analysis of Tambaqui Colossoma macropomum Fish Farming in the State of Amazonas, Brazil. Aquac. Econ. Manag 2020, 1, 1-16.

6. Pinto, E.A.S.; Liebl, A.R.S.; Nascimento, M.S.; Flor, N.S., Aride, P.H.R. Oliveira, A T. Nutrição e manejo alimentar de peixes amazônicos. In: Aquicultura na Amazônia: estudos técnico-científicos e difusão de tecnologias, 1nd ed.; Mattos, B.O., Pantoja-Lima, J., Oliveira, A.T., Aride, P.H.R., Eds.; Editora Atena: Ponta Grossa, Brasil, 2021; Volume 1, pp. 86-102.

7. Liebl, A.R.S.; Nascimento, M.S.; Aride, P.H.R.; Pantoja-Lima, J.; Bussons, M.R.F.M.; Furuya, W.M.; Oliveira, A.T. Lysine effect on the characterization of fillet, by-products, residues, and morphometry of tambaqui Colossoma macropomum (Cuvier, 1818). Lat Am J Aquat Res 2021, 49, 620-631.

8. Lazzari, R.; Neto, J.R.; Pedron, F.A.; Loro, V.L.; Pretto, A.; Gioda, C.R. Protein sources and digestive enzyme activities in jundiá (Rhamdia quelen). Sci Agric 2010, 67, 259-266.

9. Nascimento, M.S.; Mattos, B.O.; Bussons, M.R.F.M.; Oliveira, A.T.; Liebl, A.R.S.; Carvalho, T.B. Supplementation of citric acid in plant protein-based diets for juvenile tambaqui. J World Aquac Soc 2021, 52, 231-243.

10. Oliveira, A.T.; Lemos, J.R.G.; Santos, M.Q.C.; Sales, R.S.A.; Pantoja-Lima, J.; Aride, P.H.R.; Araujo, M.L.G.; Tavares-Dias, M. Morphological, cytochemical and ultrastructural aspects of blood cells in freshwater stingray species in the middle Rio Negro basin of Amazonian Brazil. Sci Rep 2021, 11, 1-11.

11. Araujo, D.M.; Pezzato, A.C.; Barros, M.M.; Pezzato, L.E.; Nakagome, F.K. Hematologia de tilápias-do-nilo alimentadas com dietas com óleos vegetais e estimuladas pelo frio. Pesqui Agropecu Bras 2011, 46, 294-302.

12. Peixe BR. Produção por Estados - Amazonas. In Anuário Peixe BR da Piscicultura, 1nd ed; Medeiros, F., Ed.; Peixe BR: São Paulo, Brazil, 2021; Volume 1, pp. 20-21.

13. Oliveira, A.M.; Silva, M.N.P.; Almeida-Val, V.M.F.; Val, A.L. Caracterização da atividade de piscicultura nas mesorregiões do estado do Amazonas, Amazônia brasileira. RECIA 2012, 4, 154-162

14. Reimer, G. The influence of diet on the digestive enzyme of the Amazon fish matrinxã, Brycon cf. melanopterum. J Fish Biol 1982, 21, 637-642.

15. Izel, A.C.U.; Pereira-Filho, M.; Melo, L.A.S.; Macêdo, J.L.V. Avaliação de níveis proteicos para a nutrição de juvenis de matrinxã (Brycon cephalus). Acta Amaz 2004, 34, 179-184.

16. National Research Council. Nutrient Requirements Tables. In Nutrient Requirements of Fish and Shrimp. 2nd ed; National Academies Press: Washington DC, USA, 2011, Volume 1, pp. 326-333

17. Percie du Sert, N.; Hurst, V.; Ahluwalia, A.; Alam, S.; Avey, M.T.; Baker, M. The ARRIVE guidelines 2.0: Updated guidelines for reporting animal research. PLoS Biol 2020, 18, e3000410.

18. Inoue, L.A.K.A.; Santos, N.C.; Moraes, G. Óleo de cravo como anestésico para juvenis de matrinxã Brycon cephalus (Gunther, 1869). Cienc Rural 2003, 33, 943-947.

19. Oliveira, A.T.; Santos, M.Q.C.; Araujo, M.L.G.; Lemos, J.R.G.; Sales, R.S.A.; Pantoja-Lima, J.; Tavares-Dias, M.; Marcon, J.L. Hematological parameters of three freshwater stingray species (Chondrichthyes: Potamotrygonidae) in the middle Rio Negro, Amazonas state. Biochem Syst Ecol 2016, 69, 33-40.

20. AOAC. Official Analytical Chemists. 21 nd ed; Association of Official Analytical Chemists: Arlington, USA, 2019. 
21. Silva, D. J.; Queiroz, A. C. Determinação da Fibra Bruta. In Análise de alimentos: métodos químicos e biológicos. 3 nd ed; UFV: Viçosa, Brazil, 2002, Volume 3, pp. 47-52.

22. Collier, H.B. The standardizations of blood haemoglobin determinations. Can Med Assoc J 1944, 50, 550-552.

23. Goldenfarb, P.B.; Bowyer, F.P.; Hall, E.; Brosious, E. Reproducibility in the hematology laboratory: the microhematocrit determination. Am J Clin Pathol 1971, 56, 35-39.

24. Kampen, E.J.; Zijlstra, W.G. Erythro cytometric methods and their standardization. Clin Chim Acta 1964, 6, 538-542.

25. Wintrobe, M.M. Variations on the size and haemoglobin content of erythrocytes in the blood of various vertebrates. Fol Haemat 1934 51, 32-49.

26. Brown, B.A. Hematology: principles and procedures. 4nd ed; Lea and Febiger: Philadelphia, USA, 1984.

27. Khaled, H.B.; Ghorbel-Belaaj, O.; Hmidet, N.; Jellouli, K.; Ali, N.E.L.; Ghorbel, S.; Nasri, M. A novel aspartic protease from the viscera of Sardinelle (Sardinella aurita): Purification and characterization. Food Chem 2011, 128, 847-853.

28. Sarath, G.; Zeece, M.G.; Penheiter, A.R. Protease assay methods. In Proetolitic enzymes - A practical approach, 2nd ed; Beyond, R.J., Bond, J.S., Eds.; Oxford: New York, USA, 2001; Volume 1, pp. 45-75.

29. Albro, P.W.; Hall, R.D.; Corbett, J.T.; Schroeder, J. Activation of non-specific lipase (EC 3.1.1.) by bile salts. Biochim Biophys Acta 1985, 835, 477-490.

30. Bernfeld, P. Amylases $\alpha$ and $\beta$ : colorimetric assay method. In: Methods in Enzymology, 1nd ed; Colowich, S.P., Kaplan, N.O., Eds.; Academic Press: New York, USA, 1955; Volume 1, pp. 149-154.

31. Ferraz, F.B.; Gomes, L.C. Social relationship as inducer of immunological and stress responses in matrinxã (Brycon amazonicus). Comp Biochem Physiol PartA Mol Integr Physiol 2009, 153, 293-296.

32. Melo, J.F.B.; Lundstedt, L.M.; Metón, I.; Baanante, I.V.; Moraes, G. Effects of dietary levels of protein on nitrogenous metabolism Rhamdia quelen (Teleostei: Pimelodidae). Comp Biochem Physiol PartA Mol Integr Physiol 2006, 145, $181-187$.

33. Yang, M.; Wang, J.; Han, T.; Yang, Y.; Li, X.; Jiang, Y. Dietary protein requirement of juvenile bluegill sunfish (Lepomis macrochirus). Aquac Res 2016, 459, 191-197.

34. Ullah, N.; Said, A.; Israr, M.; Rasool, A.; Akbar, F.; Ahmad, S.; Mehmood, S.A.; Jabeen, H.; Islam, M.; Muhammad, S.; Noureen, S.; Habiba, U.; Ahmed, D.; Shah, M.; Khan, M.A.A.; Siraj, M. Effect of different protein based feed on the growth of mahseer. Braz. J. Biol 2022, 82, e243670.

35. Lee, H.Y.M.; Cho, K., Lee, J.; Yang, S. Dietary protein requirement of juvenile giant croaker, Nibea japonica Temminck \& Schlegel. Aquac Res 2001, 32, 112-118.

36. Akpinar, Z.; Sevgili, H.; Özgen, T.; Demir, A.; Emre, Y. Dietary protein requirement of juvenile shi drum, Umbrina cirrosa (L.). Aquac Res 2012, 43, 421-429.

37. Lehninger, A.L.; Nelson, D.L.; Cox, M.M. Principles of biochemistry. 3nd ed; Worth Publishers: New York, USA, 2002.

38. Furuya, W.M.; Botaro, D.; Macedo, R.M.G.; Santos, V.G.; Silva, L.C.R.; Silva, T.C.; Furuya, V.R.B.; Sales, P.J.P. Aplicação do conceito de proteína ideal para redução dos níveis de proteína em dietas para tilápia-do-nilo (Oreochromis niloticus). Rev Bras Zootec 2005, 34, 1433-1441.

39. Castro, P.D.S.; Ladislau, D.; Ribeiro, M.W.S.; Lopes, A.C.C.; Lavander, H.D.; Bassul, L.A.; Mattos, D.C.; Liebl, A.R.S.; Aride, P.H.R.; Oliveira, A.T. Hematological parameters of three species of tucunarés (Cichla spp.) from Lake Balbina, Presidente Figueiredo, Amazonas. Braz J Biol 2020, 80, 1-7.

40. Anselmo, N.P.; Silva, C.K.P.; Franca, M.F.L.; Santos, M.Q.C.; Aride, P.H.R.; Pantoja-Lima, J.; Oliveira, A.T. Hematological parameters of captive big-headed Amazon river turtles, Peltocephalus dumerilianus (Testudines: Podocnemididae). Acta Biol Colomb 2021, 26, 207-213.

41. Dallagnol, J.M.; Higuchi, L.H.; Maluf, M.L.F.; Feiden, A.; Boscolo, W.R. Avaliação sérica de pacus submetidos a dietas com diferentes níveis de proteína e energia cultivados em tanques-rede. Acta Iguazu 2014, 3, 97-108

42. Aride, P.H.R.; Oliveira, A.M.; Batista, R.B.; Ferreira, M.S.; Pantoja-Lima, J.; Ladislau, D.S.; Oliveira, A.T. Changes on physiological parameters of tambaqui (Colossoma macropomum) fed with diets supplemented with Amazonian fruit Camu camu (Myrciaria dubia). Braz J Biol 2018, 78, 360-367.

43. Tavares-Dias, M.; Affonso, E.G.; Oliveira, S.R.; Marcon, J.L.; Egami, M.I. Comparative study on hematological parameters of farmed matrinxã, Brycon amazonicus Spix and Agassiz, 1829 (Characidae: Bryconinae) with others Bryconinae species. Acta Amaz 2008, 38, 799-805.

44. Higuchi, L.H.; Feiden, A.; Maluf, M.L.F.; Dallagnol, J.M.; Zaminhan, M.; Boscolo, W.R. Avaliação eritrocitária e bioquímica de jundiás (Rhamdia quelen) submetidos à dieta com diferentes níveis proteicos e energéticos. Cienc Anim Bras 2011,12, 70-75.

45. Ferreira, M.S.; Aride, P.H.R.; Silva, M.N.P.; Val, A.L. Efeito da quantidade de proteína na dieta e treinamento físico sobre parâmetros fisiológicos e zootécnicos de matrinchã (Brycon amazonicus, Gunther 1869). Acta Amaz 2013, 43, 439-446.

46. Puppo, D.D.; Haese, D; Gomes, L.C.; Kill, J.L.; Brugnara, E.C.; Barcellos, J.; Haddade, I.R.; Ton, N.C. Optimization of crude protein in diets for Nile tilapia reared in net pens: performance, hematology, and water quality. Cienc Rural 2017, 47, 1-7.

47. Ahmed. I.; Maqbool, A. Effects of dietary protein levels on the growth, feed utilization and haemato-biochemical parameters of freshwater fish, Cyprinus carpio var. Specularis. Fish Aquac J 2017, 8, 1-12.

48. Abdel-Tawwab, M. Effects of dietary protein levels and rearingdensity on growth performance and stress response of Nile tilapia Oreochromis niloticus (L.) Int Aquat Res 2012, 4, 1-13.

49. Glencross, B.D.; Blyth, D.; Bourne, N.; Cheers, S.; Irvin, S.; Wade, N.M. An analysis of partial efficiencies of energy utilisation of different macronutrients by barramundi (Lates calcarifer) shows that starch restricts protein utilisation in carnivorous fish. Br J Nutr 2017, 1, 1-11. 
50. Ahmed, I., Ahmad, I. Effect of dietary protein levels on growth performance, hematological profile and biochemical composition of fingerlings rainbow trout, Oncorhynchus mykiss reared in Indian himalayan region. Aquac Rep 2020, 16, 1-10.

51. Almeida, L.C.; Lundstedt, L.M.; Moraes, G. Digestive enzyme responses of tambaqui (Colossoma macropomum) fed on different levels of protein and lipid. Aquac Nutr 2006, 12, 443-450.

52. Arbeláez-Rojas, G.A.; Inoue, L.A.K.A.; Moraes, G. Atividade proteolítica e crescimento de matrinxã em natação sustentada e alimentado com dois níveis de proteína. Pesqui Agropecu Bras 2011, 46, 1521-1529.

53. Xiong, D.; Xie, C.X.; Zhang, H.J.; Liu, H.P. Digestive enzymes along digestive tract of a carnivorous fish Glyptosternum maculatum (Sisoridae, Siluriformes). J Anim Physiol Anim Nutr 2011, 95, 56-64.

54. Almeida, A.P.G.; Zardo, E.L.; Toni, C.; Behr, E.R.; Silva, L.P.; Vieira, J.P.; Loro, V.L.; Baldisserotto, B. Composition of gastrointestinal content, protease and lipase activities in summer and winter of four freshwater siluriforms (Teleostei: Actinopterygii) with two different feeding habits. Zool 2018, 35, 1-8.

55. Lundstedt, L.M.; Melo, B.J.F.; Moraes, G. Digestive enzymes and metabolic profile of Pseudoplatystoma corruscans (Teleostei: Siluriformes) in response to diet composition. Comp Biochem Physiol PartB Biochem Mol Biol 2004, 137, 331-339.

56. Gisbert, E.; Sarasquete, M.C.; Williot, P.; Castelló-Orvay, F. Histochemistry of the development of the digestive system of Siberian sturgeon during early ontogeny. J Fish Biol 1999, 55, 596-616.

Tok, N.C.; Jain, K.K.; Prabu, D.L.; Sahu, N.P.; Munilkumar, S.; Pal, A.K.; Siddiah, G.M.; Kumar, P. Metabolic and digestive enzyme activity of Pangasianodon hypophthalmus (Sauvage, 1878) fingerlings in response to alternate feeding of different protein levels in the diet. Aquac Res 2016, 48, 1-17. 